\title{
Maqasid al Shariah and Stakeholders' Wellbeing in Islamic Banks: A Proposed Framework
}

\author{
M. Fahad Siddiqi ${ }^{1}$, Shafiullah Jan ${ }^{2}$, Karim Ullah ${ }^{3}$
}

\begin{abstract}
The extant literature describes and justifies stakeholders' wellbeing as the essence of Islamic Banking and Finance (IBF). This infers the compulsion on Islamic banks to devise their operations based on inclusive wellbeing, and a greater perspective from the Maqasid al Shariah framework, and not merely converging on the compliance rulings. This paper presents a review and analysis of the present literature on Maqasid al Shariah and Stakeholders' wellbeing and synthesizes a framework for gauging the theoretical association between the classical Maqasid al Shariah and Stakeholders' wellbeing. The proposed framework can be used as a dependable framework for policy implication and future research in IBF. Moreover, concentrations of research efforts are identified from the present review and directions for future research are proposed.
\end{abstract}

Keywords: Public Wellbeing, Stakeholder's wellbeing, Islamic Banks, Maqasid al Shariah

\section{Introduction}

Islamic Banking and Finance (IBF) is growing steadily in the Islamic world and the world's leading financial hubs (Nouman, Ullah, \& Gul, 2018). Several financial institutions including world's leading banks are offering Islamic financial products around the globe (Hearn, Piesse, \& Strange, 2012). Assets of the Islamic finance industry surpass $\$ 2$ trillion mark across its three main sectors including: banking, capital markets and takaful. Total assets were valued at $\$ 2.05 \mathrm{tn}$ as of the end of 2017, marking $8.3 \%$ growth in US dollar terms year-on-year and reversing the preceding two years of near stagnation of asset value of \$1.89tn in 2016 and \$1.88tn in 2015 (Islamic Banking Bulletin: April-June 2018), and importantly this growth is multidimensional, IBF, is growing into new product-lines, sectors, and regions (Ullah \& Patel, 2011), causing a continues evolution of the discipline towards greater objectives, such as stakeholders' wellbeing and Maqasid Al Shariah (Ullah \& Al-Karaghouli, 2017).

The extant literature describes and justifies stakeholders' wellbeing as the essence

1 PhD Scholar, Institute of Management Sciences, Peshawar.Email: mfahadsiddiqi@yahoo.com 2 Assistant Professor, Institute of Management Sciences, Peshawar. Email: Shafiullah.jan@imsciences.edu.pk 3 Assistant Professor, Institute of Management Sciences, Peshawar. Email: Karim.Ullah@imsciences.edu.pk

\begin{tabular}{ll} 
ARTICLE HISTORY & \\
19 Oct, 2018 Submission Received & 22 Nov, 2018 First Review \\
\hline 4 Feb, 2019 Second Review & 8 Mar, 2019 Third Review \\
\hline 15 Mar, 2019 Accepted &
\end{tabular}


of IBF (See for example Asutay \& Harningtyas, 2015). In referring to the nature of IBF, AAOIFI (2007: 27) describes it as:

"Islamic banks were developed on a foundation that does not permit the separation between temporal and religious matters. That foundation requires compliance with Shariah as a basis for all aspects of life. This covers not only religious worship but also business transactions, which should comply with Shariah precepts."

Numerous renowned economists including Ahmed (2000); Chapra (1985); Siddiqui (2001), and Naqvi (2016) opine that IBF can be dealt as a sub component of larger Islamic Economic System. This socio-religiously constructed economic system understanding, according to Jan, Khan, and Ullah (2018) places the wellbeing of society at the center and achieves human development through fair distribution and establishment of social justice and equity as proposed by Maqasid al Shariah or the objectives of Shariah

The holistic view of the socio economic objectives for the formation of balanced society, makes the Islamic banking much more than just an institution based on the principle of interest prohibition and conforming to the legal requirements and technicalities of products and services for Shariah compliance (Haron \& Hisham, 2003; Hassan \& Musa, 2003; Jan, Ullah, \& Asutay, 2015; Nouman \& Ullah, 2014; Shinkafi \& Ali, 2017; Siddiqui, 1985; Siddiqui, 2001). In the wake of achieving the socio economic objectives, the main concern of Islamic banking is to create enduring balance between profit motive and social wellbeing for the betterment of the whole society (Ahmed, 2000; Al-Omar \& Abdel-Haq, 1996; Haron, 1995).

The wellbeing, justice, and brotherhood are the principal goals of Islam which make the wellbeing as the cornerstone of Islamic banking. This wellbeing includes of both the spiritual aspects and physical gratification of the human personality including the felicity in this world and akhirah. This facts calls for the reason that profit maximization cannot be the ultimate goal of the Muslim society, rather it should be based on social, economic and spiritual justices, which give equal human rights to all people irrespective of their ethnic or religious backgrounds (Al-Omar \& Abdel-Haq, 1996). Resultantly the conventional business institutes have profit as the ultimate goal; Islamic banks have to include both social obligation and profit as their goal (Ahmed, 2011; Ullah \& Al-Karaghouli, 2017). Only ventures that comprise of this can be aligned with the objectives of Shariah.

However, it would not be true that Islamic banks should work for charitable motives only or Islamic banks have to deal with society as the welfare organizations or fulfill the request of monetary assistance of poor and needy people. On the same 
note, it would not be appropriate for policy makers of Islamic banks to stress on the profit maximization objective only, in such a way that all other social and ethical responsibilities be negated (Haron, 1995). Islam always gives the moderate or balance view, same is in this case that banks should keep balance in their profit and social objectives. It would be against the market competition strategy if the Islamic banks do not provide enough returns (as compared to the market) to the depositors and other stakeholders who have made them in-charge of their money. Meanwhile, at the part of mangers, it will be against the risk management policies and corporate social responsibility, to focus on profits without caring about the risk associated with the investment and overlooking or ignoring their social duty and promises to the concerned parties (Chapra, 1985).

The current paper offers a glimpse of the present literature on public wellbeing and Maqasid al Shariah, and synthesizes a framework for gauging the theoretical relation between the classical Maqasid al Shariah and Stakeholders' wellbeing. Moreover, concentrations of research efforts are identified from the present review and directions for future research are proposed. The remaining paper is laid down as follows: Section 2 describes Stakeholders' Wellbeing and its different dimensions. Section 3 elaborates the Maqasid al Shariah and its different dimensions. Section 4 synthesizes the framework of stakeholders' wellbeing (FSW). The present contributions, research gaps and future directions are proposed in the section 5 . Section 6 concludes the paper.

\section{Public Wellbeing and Stakeholders Wellbeing}

In the recent years public well-being has received a lot of attention not only in research and media but also in the policy and statistical agenda of most of the countries. So far, most of the efforts concerning the development of better measures of public well-being, or implementation of the policies for public well-being have confined to policy and academic circles, while the corporate sector has a very limited role in the development and implementation of this agenda. However, firms can play a key role in shaping and delivering public wellbeing, since they deliver most of the goods and services that people enjoy in their daily life. Moreover, firms shape the social and work place environment for their employees, which in turn directly influence their quality of life and work.

The word "public" can be described as the largest possible sphere of the society, which includes people in general, or all the peoples in a particular community or country. The term "public" is interpreted differently in different contexts e.g., for a government the public may be the aggregate of the citizens of a municipality, state, or country, while for a firm "public" include all possible stakeholders of the society including customers, employees, labor unions, suppliers and shareholder. 
The term "public" is used interchangeably for 'stakeholders' in the public relations and management literature (Ahmed, 2000; Grunig \& Repper, 1992). However, some authors differentiate between public and stakeholders and consider stakeholders as the subset of public (see for example Rawlins, 2006). In Islamic banking literature, these two terms are usually used synonymously. Moreover, the conceptual models for stakeholders wellbeing are based on the public wellbeing theories (see for example Azhar Rosly \& Afandi Abu Bakar, 2003; Bedoui \& Mansour, 2015; Farook, Kabir Hassan, \& Lanis, 2011; Hassan \& Musa, 2003). Therefore, in the present study the terms 'public wellbeing' and 'stakeholder wellbeing' are used synonymously.

Table 1 presents the attributes of wellbeing

Table 1: Attributes of Wellbeing

\begin{tabular}{|c|}
\hline $\begin{array}{l}\text { Spiritual wellbeing } \\
\text { It incorporates an expanded feeling of satisfaction and feeling of association with } \\
\text { prominent' than oneself, and it additionally contains adapting more about "your } \\
\text { recognizing the core qualities and values you have. (Brown \& Alcoe, } 20\end{array}$ \\
\hline $\begin{array}{l}\text { Physical wellbeing } \\
\text { Physical wellbeing is one of the most commonly used term to measure the health or physic } \\
\text { ing. Physical wellbeing has its own paradigm, which shows about the individual's self-care, } \\
\text { nutrition and overall physical state. (Brown \& Alcoe, 2010; Foster, Keller, \& Boomer, } 2\end{array}$ \\
\hline $\begin{array}{l}\text { Occupational wellbeing } \\
\text { It incorporates the level of happiness one drives from work, and the point of confinement to which } \\
\text { one's occupation accommodates his abilities and qualities. It envelops working conditions and the } \\
\text { condition the work environment is protected or upsetting these elements can add to one's wellbe- } \\
\text { ing and prosperity(Lightman, Mitchell, \& Wilson, 2008) }\end{array}$ \\
\hline $\begin{array}{l}\text { Social wellbeing } \\
\text { It shows the level of friendship and engagement of an individual with other human beings, society } \\
\text { and nature (Brown \& Alcoe, 2010; Foster et al., 2007). Social wellbeing can be explained through } \\
\text { capturing the behavior of individual with society and environment e.g., volunteer work (May, } \\
\text { Cheney, \& Roper, 2007) the features of human being like giving charity and work for humanity } \\
\text { also indicates the social wellbeing level of individuals (Charities Aid Foundation, 2010, p.1). }\end{array}$ \\
\hline $\begin{array}{l}\text { Psychological wellbeing } \\
\text { This kind of wellbeing incorporates conduct, sentiments, cognitive approach, feelings, and ind } \\
\text { ual behavior. It can be captured through the indicators like happiness, satisfaction from achie } \\
\text { ments of life, and positive mental health (Hamilton \& Redmond, 2010). }\end{array}$ \\
\hline $\begin{array}{l}\text { Economic wellbeing } \\
\text { One of the oldest indicators of economic wellbeing is Gross Domestic Product (GDP). The Index } \\
\text { of Economic wellbeing (IEWB) suggests that broader worldview of the concept of economic wellbe- } \\
\text { ing is required to capture the economic wellbeing in real sense, which may include the average level } \\
\text { of consumption, the average level of savings, size of middleclass in the society and economic secu- } \\
\text { rity (Osberg, 2014). Income level is the key factor of economic wellbeing as it helps the individual } \\
\text { to access the basic utilities of life like safe and secure shelter, hygienic living conditions and proper } \\
\text { food for family (Lightman et al., 2008). }\end{array}$ \\
\hline
\end{tabular}




\section{Intellectual wellbeing}

Intellectual wellbeing can be explained using questions like how good is the individual in solving problems using cognitive capabilities? And how positive is the individual in facing issues of life so that he can overcome the problem (Brown \& Alcoe, 2010; Foster et al., 2007). Literacy and education are thought to be imperative components for accomplishing intellectual wellbeing, as these factors influence a person's wellbeing and prosperity by empowering methods for dealing with stress and other fundamental capabilities (Lightman et al., 2008).

\section{Cultural wellbeing}

It shows the openness towards other's culture and acceptance of one's own cultural values (Brown \& Alcoe, 2010; Foster et al., 2007). Factors like values, ethnicity, religion and willingness in speaking mother tongue describes the cultural wellbeing.

The extant literature has mentioned different dimensions of public wellbeing. Table 2: presents the development of these attributes in the extant literature.

\begin{tabular}{|c|c|c|c|c|c|c|c|c|c|c|c|c|}
\hline ¿̇ं & & & & & & $>$ & $>$ & & $>$ & $>$ & & $>$ \\
\hline$\dot{\bar{J}}$ & & & $>$ & & & $>$ & $>$ & $>$ & $>$ & $>$ & $>$ & $>$ \\
\hline 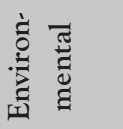 & & & $>$ & $>$ & $>$ & $>$ & $>$ & $>$ & $>$ & $>$ & $>$ & $>$ \\
\hline 芦 & $>$ & & & $>$ & $>$ & $>$ & $>$ & & $>$ & $>$ & & $>$ \\
\hline के & $>$ & & $>$ & $>$ & $>$ & $>$ & $>$ & $>$ & $>$ & $>$ & & $>$ \\
\hline 递 & $>$ & $>$ & & $>$ & $>$ & $>$ & $>$ & & $>$ & $>$ & & $>$ \\
\hline के & $>$ & $>$ & $>$ & $>$ & $>$ & $>$ & $>$ & $>$ & $>$ & $>$ & & $>$ \\
\hline 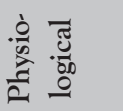 & $>$ & & $>$ & $>$ & $>$ & $>$ & $>$ & $>$ & $>$ & $>$ & $>$ & $>$ \\
\hline 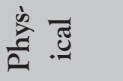 & $>$ & $>$ & $>$ & $>$ & $>$ & $>$ & $>$ & $>$ & $>$ & $>$ & & $>$ \\
\hline 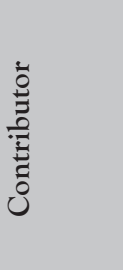 & 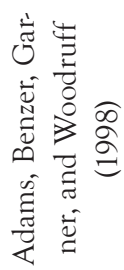 & 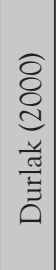 & 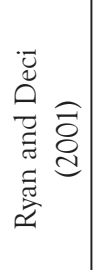 & 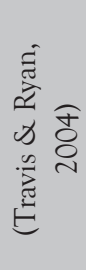 & 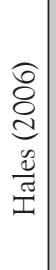 & 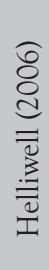 & 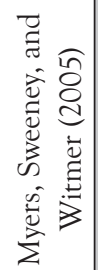 & 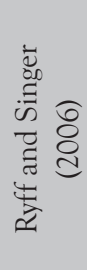 & 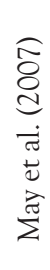 & 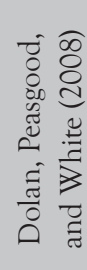 & 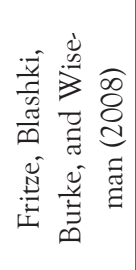 & 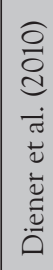 \\
\hline
\end{tabular}


The same dimensions of public wellbeing are also mentioned in the classical Islamic economics literature. Table 3 presents the development of these attributes in the classical Islamic economic literature.

\begin{tabular}{|c|c|c|c|c|c|}
\hline 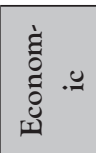 & $>$ & & & & \\
\hline$\frac{\bar{\Xi}}{\tilde{E}}$ & & & & $>$ & \\
\hline 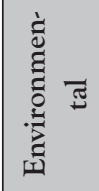 & & & & & \\
\hline 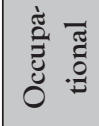 & & & $>$ & & \\
\hline 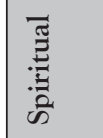 & $>$ & $>$ & $>$ & $>$ & $>$ \\
\hline 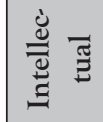 & $>$ & $>$ & $>$ & & $>$ \\
\hline 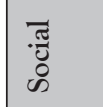 & $>$ & $>$ & $>$ & $>$ & $>$ \\
\hline 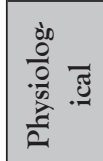 & & $>$ & & $>$ & \\
\hline $\begin{array}{l}\frac{\vec{d}}{\frac{0}{2}} \\
\frac{e}{2}\end{array}$ & & & $>$ & & \\
\hline 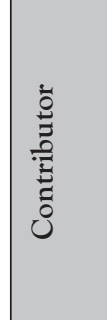 & 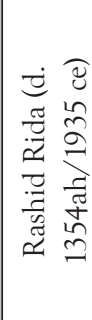 & 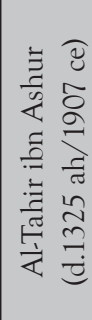 & 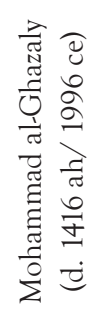 & 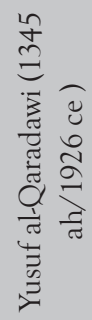 & 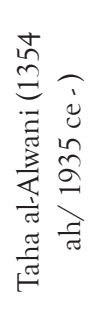 \\
\hline
\end{tabular}




\section{Maqasid al Shariah}

Islam envisions a social order in terms of economics that provides social justice and economic growth (Ashur \& Al-Tahir, 2006; Bedoui \& Mansour, 2015). The aspired vision has strong foundations in the objectives or goals of Shariah which are known as Maqasid al Shariah (Dusuki \& Abozaid, 2007). Maqasid al Shariah hold the key to the human life (Mohammad \& Shahwan, 2013) and provide direction to it. If the Maqasid al Shariah are not observed, there would be uncertainty and chaos. Therefore, Islam has emphasized on the importance of Maqasid al Shariah for the guidance of human life. A purposeless and directionless life would hold no meaning.

The core purpose and objectives of Shariah have been explored by several scholars. Scholars from different school of thoughts including Abu Ishaq al-Shatibi (the Malikite), al-'Izzibn 'Abd al-Salam (the Shafite), and Ibn Qayyim al-Jawziyyah (the Hanbalite) gave rise to exceptionality (Diaw, Bacha, \& Lahsasna, 2012). Ibn Qayyim al-Jawziyyah (d.1356) states that the interest of people in both the worlds is aimed to be safeguarded by Shariah. According to Al-Ghazali, Maqasid al Shariah is referred as: "the promotion of human being's welfare is the purpose of Shariah which indicates that their faith, lives, their wealth, prosperity and intellectuality be protected. The public interest is ensured and served by these fundamental factors and are considered to be important" (Al-Ghazali, 1356/1937, pp. 139-140); (see also Chapra, 1985; Chapra, 2016). The list and sequence of fundamental factors indicated by Al-Ghazali is approved by Al-Shatibi, proving that the basic purpose and essence of Shariah is reflected in these fundamentals, showing a theme of harmony (Ashur \& Al-Tahir, 2006).

According to Mohammad and Shahwan (2013) the earliest discussion about Maqasid was initiated by a renowned scholar Al-Shatibi. The terminology was published in his work Al-Muwafaqat. He opined that the objectives or Maqasid are observed in two scenarios; "the objective of Shariah (the Law) and the objective of Mukallaf" (the performer). Maqasid al Shariah encompasses all elements that pertain to the human nature or fitrah. The classical economics literature has highlighted different dimensions of Maqasid al Shariah. Table 4 reports the major dimensions of Maqasid al Shariah as highlighted in the classical Islamic economics literature.

\subsection{Classical Model of Maqasid al Shariah}

Numerous Islamic scholars have attempted to identify comprehensive and meaningful objectives of Islamic Shariah namely Maqasid al Shariah. Conclusively all the scholars come up with almost similar ideas, which drives identical objectives. Sheikh Mohamad Abu Zahrah, a renowned Scholar from Egypt viewed the Maqasid al Shariah with the lens of "Mercy to Humanity" in his book Usual Al Fiqh. Imam Abu Zahrah 
Table 4: Dimensions of Maqasid al Shariah in the Classical Islamic Economics literature

\begin{tabular}{|c|c|}
\hline Source & Dimensions of Maqasid al Shariah \\
\hline $\begin{array}{l}\text { Rashid Rida (d. } 1354 \mathrm{ah} / 1935 \\
\text { ce) }\end{array}$ & $\begin{array}{l}\text { Islam is the religion of nature, knowledge, proof, independence, } \\
\text { freedom; political, economic, and social responsibility, and equal } \\
\text { gender rights, and wisdom }\end{array}$ \\
\hline $\begin{array}{l}\text { Al-Tahir ibn Ashur (d. } 1325 \\
\text { ah/ } 1907 \mathrm{ce})\end{array}$ & $\begin{array}{l}\text { Facilitation, freedom, the safeguard of original natural instincts } \\
\text { and equality. }\end{array}$ \\
\hline $\begin{array}{l}\text { Mohammad al-Ghazaly (d. } 1416 \\
\text { ah/ } 1996 \text { ce) }\end{array}$ & Freedom and justice \\
\hline $\begin{array}{l}\text { Yusuf al-Qaradawi (1345 } \\
\text { ah/1926 ce - ) }\end{array}$ & $\begin{array}{l}\text { Calling people to worship God, building a strong Islamic nation } \\
\text { purifying the soul, preserving true faith, restoring moral values, } \\
\text { maintaining human dignity and rights, treating women fairly, } \\
\text { building good families, and striving for world based on coopera- } \\
\text { tion. }\end{array}$ \\
\hline $\begin{array}{c}\text { Taha al-Alwani (1354 ah/ } 1935 \\
\text { ce - ) }\end{array}$ & $\begin{array}{l}\text { Developing civilization on earth, purging of the soul (tazkiyah), } \\
\text { and the monotheism or oneness of God (tawhid) }\end{array}$ \\
\hline
\end{tabular}

categorized Maqasid al Shariah into three broader categories including: educating the individual (Tahdhib al-Fard), establishing justice (Iqamah al-Adl) and Public Interest (al-Maslahah). Figure 1 presents the Abu Zahrah's model of Maqasid al Shariah.

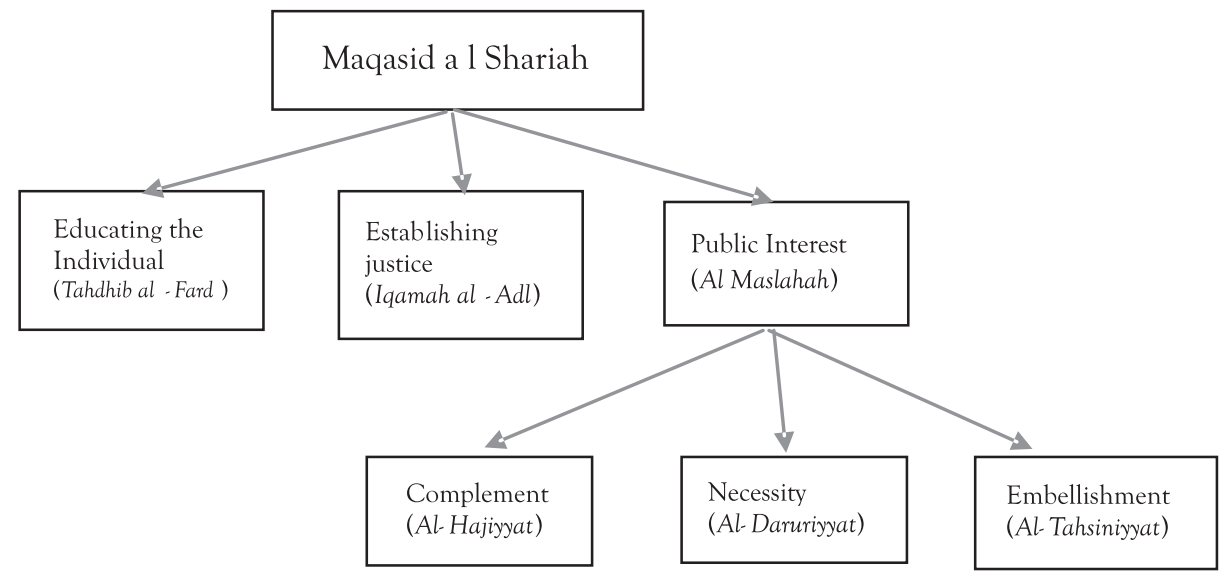

Figure 1: Abu Zahrah's model of Maqasid al Shariah.

\subsubsection{Educating the individual (Tahdhib al-Fard)}

Tahdhib is referred to the development of human beings, which not only focus on skills and knowledge but also spiritual values. Educating individuals can be viewed in the broader spectrum of falah or success for both the worlds (Jan, Ullah \& Khan, 2015 (Jan et al., 2018)). Education is needed for individuals so that one can become good human beings. Individuals and their lives are the focus of Islamic preaching. So 
education is needed for individuals to be trustworthy and righteous.

\subsubsection{Establishing justice (Iqamah al'Adl)}

Establishing justice between the individuals and community is regarded as the second objective as Quran has specific directions about justice \{Indeed, Allah commands justice ... (An-Nahl 16:90) as Allah Almighty in the Qur'an commands people to \{stand firmly for justice.\} (An-Nisaa' 4:135). Establishing justices is very noble cause in Islam, so it is endorsed in every aspect of life.

\subsubsection{Realization of benefit (Maslahah)}

Shariah pinpoints the benefits for humanity and real benefit is grounded on the concept of (Mashalah). As commands of Maqasid are either for providing some benefits to humanity or protecting humanity from any harm. Islamic Scholars have described Maslahah as: "the preservation of Shariah objectives", (Khan, 2010). According to Kamali (2008) Maslahah comprises of the vital objectives of Shariah. Masalah has been broadly classified into three main splits by many Muslim scholars including Abu Zahrah and Imam Ghazali i.e. daruriyyat (necessities or essentials), hajiyyat (complement), and tahsiniyyat (embellishments).

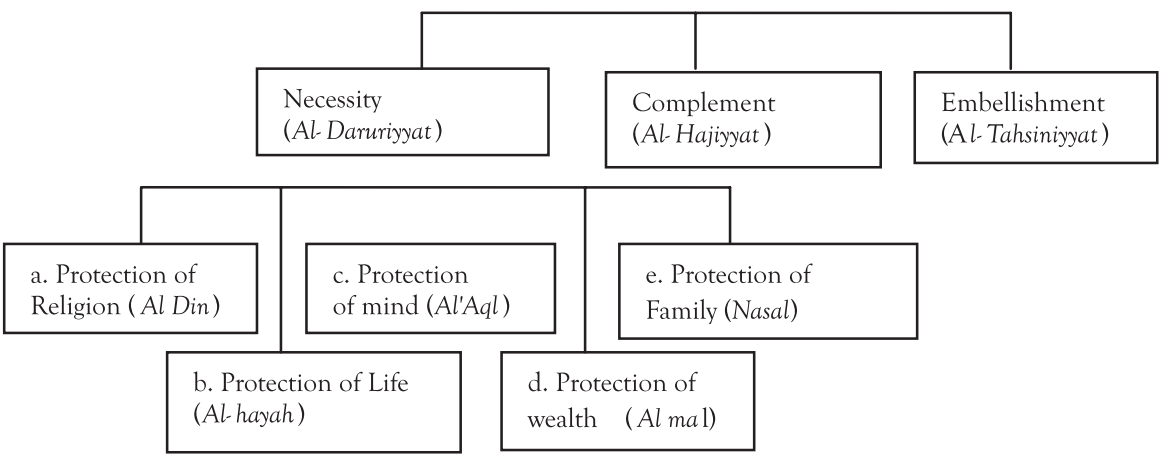

Figure 2: Imam Ghazali Model of public wellbeing (Masalah)

Daruriyyat are considered fundamental which cannot be ignored for the welfare and wellbeing of human beings in both the worlds (Here and Hereafter). The consequence of neglecting and avoiding essentials would be the destruction of all the humans of society and may lead to the destruction of the whole environment. Imam Ghazali has classified daruriyyat or the essentials Mashalah in five major categories namely, a. Protection of Religion (Al-Din), b. Protection of Life (Al-hayah), c. Protection of Mind (Al'Aql), d. Protection of Wealth (Al mal), e. Protection of Family/Linage (Nasal). Figure 2 presents the Imam Al Ghazali's model of Masalah.

The essentials are considered to be complemented with the needs which are 
known as hajiyyat. Although, the normal life order is not thought to be destructed in the absence of these needs unlike essentials. (Diaw et al., 2012; Nyazee, 2002). The complementary necessities are defined by Ashur and Al-Tahir (2006) as follows: Hajiyyat comprises all those needs that are required by the community so that their interests may be achieved and the various functions and activities of their life may be performed normally. However, in case, these needs are neglected, the destruction of social life order may not occur but their functions may get affected. Similarly, hajiyyat are not up to the level that people may be considered indispensable (daruri) as discussed by Ibn Ashur (2006).

The matters that lead towards the advancements in the society as well as provide guidance related to different aspects of life are related to the third important factor i.e. embellishments or tahsiniyyat. The guidelines of Shariah include admirable illustrations such as clean body and eagerness to offer prayer, giving donations, contribution towards improvement of poor, avoidance of lavish life style and recommendation to others as well to offer supererogatory prayers ('ibadat). The crux of all these guidelines is to achieve passion, integrity as well as excellence concerning various domains of human life and behaviors. However, the normal functions and activities of humans in the society can be performed even in the absence of these values. These values and matters can be illustrated as: voluntary i.e. sadaqah, ethical value, moral values, and many others as indicated by different scholars (See for example Dusuki \& Bouheraoua, 2011; Ibn Ashur, 2006; Lahsasna \& Sulaiman, 2010 (Lahsasna \& Sulaiman, 2010)).

\section{The Framework of Stakeholders' Wellbeing (FSW)}

This section synthesizes a framework of stakeholders' wellbeing (FSW) to conceptualize the conceptual association between the classical framework of Maqasid al Shariah and the general framework of public wellbeing (Stakeholder). Figure 1 presents the pre-empirical framework of stakeholders' wellbeing.

The FSW shows the logical link between the Maqasid al Shariah and different dimensions of public wellbeing in the contemporary economics and Islamic finance literature. The framework has been evolved in three different phases of research. In the first phase the concept of Maqasid al Shariah is conceived using one of the authentic sources of $18^{\text {th }}$ century, that is Abu Zahrah model. In Abu Zahra model the Maqasid al Shariah have been elaborated using three facets including: educating the individual (Tahdhib al-Fard), establishing justice (Iqamah al'Adl) and Public wellbeing (al-Maslahah) (Jazil, 2013; Mohammad \& Shahwan, 2013).

In second phase of conceptualization the sub dimensions of public wellbeing (al-Maslahah) were explored. Following Imam Al Ghazali and Imam Shatibi's school 


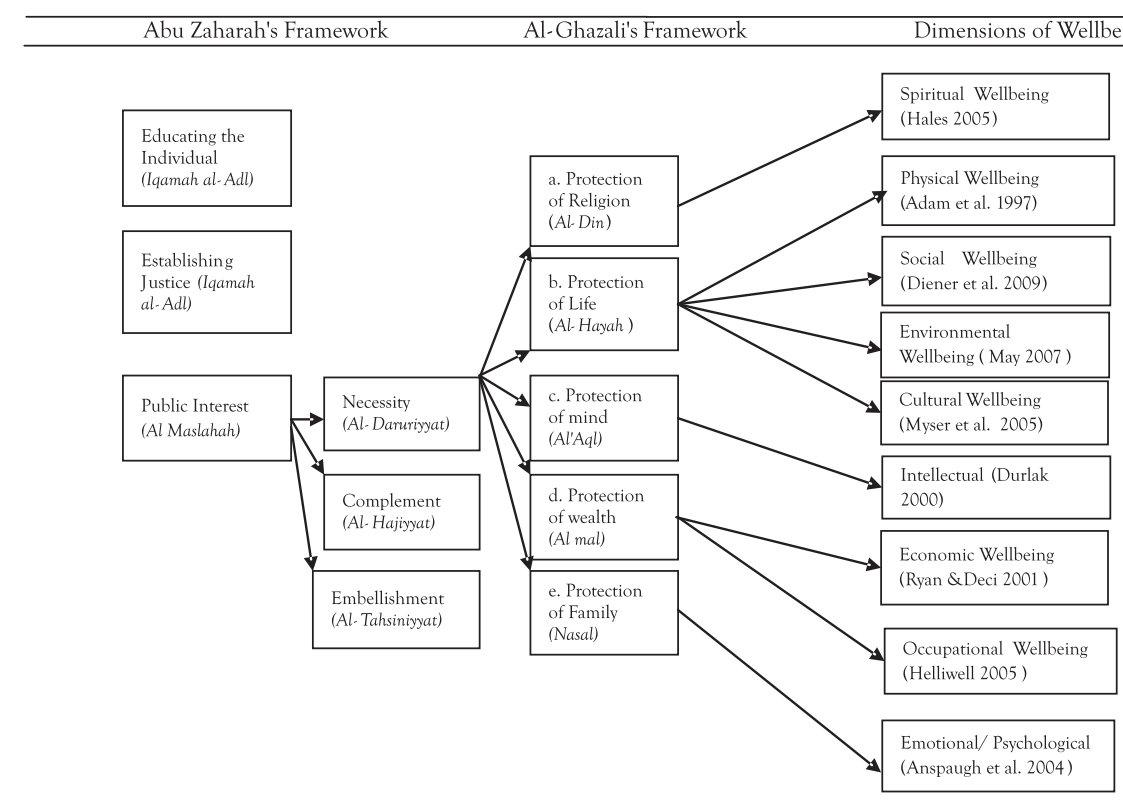

Figure 3: The Framework of Stakeholders' Wellbeing (FSW) (Extended from Muhammad $\&$ Shahwan, 2013)

of thought, the public wellbeing (al-Maslahah) has been further divided into three categories namely daruriyyat (necessities or essentials), hajiyyat (complement), and tahsiniyyat (embellishments). Among these the most important dimension of public wellbeing (al-Maslahah) is Daruriyyat (the necessities). Following Imam Al Ghazali, Daruriyyat is further divided into five subdivisions i.e. a. Protection of Religion (AlDin); b. Protection of Life (Al-hayah); c. Protection of mind (Al 'Aql); d. Protection of wealth (Al mal); e. Protection of Family (Nasal).

In the last phase of conceptualization of framework the aim was to build the linkage between the five broad dimensions of Daruriyyat (the necessities) and the conventional dimensions of wellbeing. For this very purpose, various dimensions of wellbeing have been explored in different academic disciplines (Section 3.4). Nine dimensions of wellbeing have been found in literature namely: spiritual, physical, social, economic, environmental, cultural, intellectual, occupational, and psychological. These dimensions have been linked with the five broader sub dimensions of Maqasid al Shariah.

\section{Public Wellbeing in Islamic banking and Finance: The Present Contributions and Future Directions}

With respect to IBF, Maqasid al Shariah refers to the inclusive aim and objective 
meanings that the Shariah attempts to accomplish through its rulings, principles and guidelines related to financial activities and economic activities (Akram Laldin, 2008). The fundamentals of Islamic finance and economics are grounded on the conceptions of economic wellbeing, justice, universal brotherhood, social welfare and equitable distribution of income. The results of these broader guidelines are the social freedom, social justices and overall wellbeing of every individual of the society. Through examination of these fundamental guidelines or principle, it can be identified that none of them addresses the profit maximization motive directly nor the motive of Falah (success after this life); but these highlight the importance of the balance society even for Islamic Banking it provides the same platform. In short Maqasid al Shariah have the broader scope of seeing the things moving in developed phase with the benefits of this life and hereafter (din-o-dunia) (Al-Mubarak \& Osmani, 2010).

The extant literature suggests that there are two dissenting opinions regarding the objectives of Islamic Banking. One concept is mentioned by Chapra's model, which explains the Islamic banking objective with the lens of socio-economic purpose (Lewis \& Algoud, 2001). According to the proponents of this view including Azhar Rosly and Afandi Abu Bakar (2003); Iqbal and Molyneux (2005); Siddiqui (1985); Siddiqui (2001) and (Naqvi, 2016), the Islamic bank must not be exclusively profit oriented. Rather it has to intend at promoting Islamic values and norms in addition to shielding the needs of Islamic society all together. This model places better religious commitments and social welfare, which leads Islamic banks towards the Islamic economic objectives (like equitable distribution of income and wealth and social justice) which promotes economic development. The Chapra's model, therefore, is supposed to be harmonious with the strength of Shariah and by and large the Islamic lens. Consequently, Islamic banks must endorse social welfare activities and programs and build more assistance headed for the deprived and the unfortunate people without discouraging its commercial feasibility.

Alternatively, framework of Ismail, views the Islamic banks as a standard commercial entity which has the exclusive liability of carrying out business in a way which is dependable in context to Islamic law (Lewis \& Algoud, 2001; Satkunasegaran, 2003). This model explains that Islamic Banks have to focus primarily on wellbeing of their depositors and the shareholder, whereas all the other stakeholders including sociality, government and environment should be the secondary focus. Conclusive, Islamic Banks have to pay only Zakat as their only social responsibility. On the other hand, the utilization of depositor's money or stakeholder's fund for any other social activities, which are not obligatory by the law may put the viability of Islamic banking at risk. This view is somehow similar to the Western neo-classical worldview, particularly Friedman's. In this outline, profit maximization is the merely justifiable and 
dominant objective of any commercial institution, conditioned that it is working in the given frame of reference(Dusuki \& Bouheraoua, 2011).

Perceptibly, one cannot find any significant difference between the two models but only in degree and emphasis. Both models highlighted the importance of social and moral responsibility, one model defines it directly and second model describes it conversely. Chapra's model is focused on the betterment of society in the first place, whereas Ismail's view has an emphasis on the sustainable and profitable functioning of Islamic banks, which ultimately results in high moral and social outputs.

It is evident from the preceding discussion that extant literature describes and justifies stakeholders' wellbeing as the essence of IBF (See for example Al-Mubarak \& Osmani, 2010; Asutay \& Harningtyas, 2015). According to (Asutay \& Harningtyas, 2015) IBF has been sensed by the world in mid-1970s in the structure of Islamic commercial banking as a value based banking system which should be based on principles of Islamic ethics, values, social and Islamic legal norms. Such ethical-financial system will be based on the two strong pillars namely financial and religious, which is tied up with the self-evident approach of Islamic Moral Economy (IME), which explains Maqasid al Shariah as a source of ultimate wellbeing of mankind (Asutay, 2012).

This suggests the essentialness on the Islamic banking policy makers to device their operations grounded on the overall welfare and a greater standpoint from the Maqasid al Shariah framework, and not just concentrating on the Shariah compliance. However, contrasting to the prospects of the advocates of Islamic banking, the contemporary practices of the Islamic banks, in many cases, are not in conformity with the Shariah required standards (Jan, 2011).

(Asutay, 2012) claim that contemporary practices of Islamic financial institutions are moving away from their basic philosophy. This is because Islamic Banks are trying to copy the conventional banking and their more focus is on form (legal requirements) while less focus is given to the substance (the social wellbeing) identified in the Maqasid al Shariah framework (Ahmed, 2000).

Similarly, according to Dusuki (2008b) a number of facts identified by the researchers indicate that the objective of social wellbeing for Islamic banks is still a dream. This is for the reason that the massive literature on Islamic banking is underpinning only on economic and commercial features of Islamic Banking, while the social issues addressing the practices of Islamic banks are usually consigned to the back seat in the argument. This become principally factual once particular researcher refer Islamic banking same as the conventional banking apart from conforming with Shariah rules with reference to product development only (El-Gamal, 2006; Ismail, 2002). Concept 
emphasizes that Islamic Banking should be considered a commercial entity same as the commercial banking, but should be aligned with Islamic Shariah. Activities like social welfare or wellbeing should be addressed by other entities like Government (Lewis \& Algoud, 2001; Satkunasegaran, 2003).

It is consequently important to evaluate the performance of Islamic financial institutions like banks in relation to IME's Basic module, as the latter explore the underlying principle for the materialization of Islamic Business and Finance (IBF) (Asutay \& Harningtyas, 2015). This will assist to position by what means the IBF institutions are bound for satisfying the multidimensional advancement an alternative of 'economic financialization'; and convene both 'form' (fiqh which comprise of rulings Islamic Law) along with 'substance' (social and moral filters) (Asutay, 2012).

Consistent with this view, several studies attempt to evaluate the performance of Islamic banks in terms of stakeholders' wellbeing (See for example,Abdul Razak, Mohamed, \& Md Taib, 2008; Bedoui \& Mansour, 2015; Ismail \& Arshad, 2010; Jazil, 2013; Mohammed \& Taib, 2015; Yusob et al., 2015). However, the extant literature is limited in several ways.

Shinkafi and Ali (2017) conducted a systematic review of the literature on Maqasid al Shariah in Islamic economics, finance, and banking with the aim of integrating the research efforts and highlighting the research gaps. Scholars found that an important concentration apparent within the extant literature is the overwhelming focus on the Islamic banks' performance using Maqasid-based model. However, studies concluded that a cohesive guide on wellbeing in the context of IBF and Islamic economics is missing that could serve the need of the IBF industry. Secondly, most of the studies have used classical models of stakeholders' wellbeing for scaling the performance of Islamic banks with respect to stakeholders' well being (See for exampleAsutay \& Harningtyas, 2015; Bedoui \& Mansour, 2015; Dusuki \& Abdullah, 2007). Therefore, there is a need for a comprehensive framework of wellbeing consistent with the principles of Shariah that could define the criteria and intention, values and ethics, and set-ups of the Islamic financial institutions.

Similarly, few studies have identified the important dimensions of stakeholders' wellbeing that should be focused by Islamic banks (See for example, Dusuki, 2008a). However, a little is known about the reach of Islamic banking operations in terms of addressing different dimensions of stakeholders' wellbeing. Few studies attempt to assess the stakeholders' wellbeing in the operations of Islamic financial institutes and banks. However, these studies have focused the secondary financial data of Islamic banks and measured the performance of Islamic banks in terms of stakeholders' wellbeing by considering the expenditures in different avenues e.g., training and 
development, public awareness, and social welfare etc, the financing mechanism, and the distribution mechanism of Islamic banks (See for example Asutay \& Harningtyas, 2015; Bedoui \& Mansour, 2015; Mohammed \& Taib, 2015). However, literature lacks insight on the practitioners' point of view on the IFIs ability to ensure the wellbeing of stakeholders. Therefore future studies should bridge this gap by developing a holistic framework of stakeholders' wellbeing within the operations of Islamic banks. This framework should help in conceptualizing how Islamic banks address different dimensions of stakeholders' wellbeing through their operations and the typology of these dimensions and their sub-elements.

\section{Conclusion}

Maqasid al Shariah forms the bases of religious directives or edicts to fulfill the needs of human beings for the welfare of humans (Al-Raysuni, 2005). Maqasid al Shariah is the pinnacle of wellbeing of mankind. It helps in the development of society and wellbeing of human being for achieving human perfection here and in hereafter (Esen, 2015). Maqasid al Shariah is thus a tool which tells if the reform program conforms to the objectives, principles, and value of Islamic Shariah or law. These objectives cover all facets of human actions and activities from political, moral, spiritual, environmental, economical, and universal spheres of human society.

Maqasid al Shariah helps in the establishment of justice, elimination of unfairness and diminution of deprivation. Moreover, aversion of people against wrong deeds is also aspired by it. The purpose behind maintaining justice is to establish equilibrium so that on one hand, the rights, duties and responsibilities may be duly accomplished and on the other hand, unfair deeds and inequality concept may be vanished. In the nutshell Maqasid al Shariah ensure the sound provision of benefits to humans of the community along with protection of their welfare. Therefore, the livelihood of people in this world and their eternal life is greatly associated with it.

\section{References}

Abdul Razak, D., Mohamed, M., \& Md Taib, F. (2008). The performance measures of Islamic banking based on the Maqasid framework. Paper presented at the IIUM International Accounting Conference INTAC IV Putra Jaya Marroit Malaysia, best paper.

Adams, T., Benzer, J., Garner, L., \& Woodruff, S. (1998). Construct validation of the perceived wellness survey. American Journal of Health Studies, 14(4), 212-219.

Ahmed, H. (2011). Maqasid al-Shari'ah and Islamic financial products: A framework for assessment. ISRA International Journal of Islamic Finance, 3(1), 149-160.

Ahmed, K. (2000). Islamic finance and banking, the challenge and prospects. Review of Islamic Economics, 
9(1), 57-82.

Akram Laldin, M. (2008). Islamic financial system: The Malaysian experience and the way forward. Humanomics, 24(3), 217-238.

Al-Mubarak, T., \& Osmani, N. M. (2010). Applications of Maqasid al-Shari'ah and Maslahah in Islamic banking practices: An analysis. Paper presented at the International Seminar on Islamic Finance in India, 4 - 6 October 2010, Kochi, India. (Unpublished).

Al-Omar, F., \& Abdel-Haq, M. (1996). Islamic banking: Theory, practice, and challenges: Zed Books.

Al-Raysuni, A. (2005). Imam al-Shalibi's theory of the higher objectives and intents of Islamic law (Nancy Roberts, Trans.). Herndon, USA : The International Institute of Islamic Thought.

Ashur, I., \& Al-Tahir, M. (2006). Treatise on Maqasid al-Shari'ah. Herndon, USA: The International Institute of Islamic Thought

Asutay, M. (2012). Conceptualising and locating the social failure of Islamic finance: Aspirations of Islamic moral economy vs the realities of Islamic finance. Asian and African area Studies, 11(2), 93-113.

Asutay, M., \& Harningtyas, A. F. (2015). Developing Maqasid al-Shari'ah index to evaluate social performance of Islamic banks: a conceptual and empirical attempt. International Journal of Islamic Economics and Finance Studies, 1(1), 5-64.

Azhar Rosly, S., \& Afandi Abu Bakar, M. (2003). Performance of Islamic and mainstream banks in Malaysia. International Journal of Social Economics, 30(12), 1249-1265.

Bedoui, H. E., \& Mansour, W. (2015). Performance and maqasid al-shari'ah's pentagon-shaped ethical measurement. Science and Engineering Ethics, 21(3), 555-576.

Brown, C., \& Alcoe, J. (2010). The heart of wellbeing. Journal of Holistic Healthcare, 7(1), 24.

Chapra, M. U. (1985). Towards a just monetary system. Leicester, UK: The Islamic Foundation.

Chapra, M. U. (2016). The future of economics: An Islamic perspective (Vol. 21): Kube Publishing Ltd.

Diaw, A., Bacha, O. I., \& Lahsasna, A. (2012). Incentive-compatible Sukuk musharakah for private sector funding. ISRA International Journal of Islamic Finance, 4(1), 39-80.

Diener, E., Wirtz, D., Tov, W., Kim-Prieto, C., Choi, D.-w., Oishi, S., \& Biswas-Diener, R. (2010). New well-being measures: Short scales to assess flourishing and positive and negative feelings. Social Indicators Research, 97(2), 143-156.

Dolan, P., Peasgood, T., \& White, M. (2008). Do we really know what makes us happy? A review of the economic literature on the factors associated with subjective well-being. Journal of Economic Psychology, 29(1), 94-122.

Durlak, J. A. (2000). Health promotion as a strategy in primary prevention. In D. Cicchetti, J. Rappaport, I. Sandler, \& R. P. Weissberg (Eds.), The promotion of wellness in children and adolescents (pp. 221-241). 
Washington, DC, US: Child Welfare League of America.

Dusuki, A. W., Bouheraoua, S. (2011). The framework of Maqasid Shariah and its implications for Islamic finance. Islam and Civilisational Renewal, 2(2), 317-336

Dusuki, A. W. (2008a). Understanding the objectives of Islamic banking: A survey of stakeholders' perspectives. International Journal of Islamic and Middle Eastern Finance and Management, 1(2), 132-146.

Dusuki, A. W. (2008b). What does Islam say about corporate social responsibility. Review of Islamic Economics, 12(1), 5-28.

Dusuki, A. W., \& Abdullah, N. I. (2007). Maqasid al-shari'ah, Maslahah and corporate social responsibility. The American Journal of Islamic Social Sciences (AJISS), 24(1), 25-45.

Dusuki, A. W., \& Abozaid, A. (2007). A critical appraisal on the challenges of realizing Maqasid al-Shariah in Islamic banking and finance. IIUM Journal of Economics and Management, 15(2), 143-165.

El-Gamal, M. A. (2006). Islamic finance: Law, economics, and practice: Cambridge University Press.

Esen, M. F. (2015). A statistical framework on identification of Maqasid Al-Shariah variables for socio-economic development index. Journal of Business Studies Quarterly, 7(1), 107-124.

Farook, S., Kabir Hassan, M., \& Lanis, R. (2011). Determinants of corporate social responsibility disclosure: The case of Islamic banks. Journal of Islamic Accounting and Business Research, 2(2), 114-141.

Foster, L. T., Keller, C. P., \& Boomer, J. (2007). Defining wellness and its determinants. British Columbia Atlas.

Fritze, J. G., Blashki, G. A., Burke, S., \& Wiseman, J. (2008). Hope, despair and transformation: climate change and the promotion of mental health and wellbeing. International Journal of Mental Health Systems, 2(1), 13-23.

Grunig, J. E., \& Repper, F. C. (1992). Strategic management, publics, and issues. Excellence in Public Relations and Communication Management, 73(1), 117-157.

Hales, D. (2006). An invitation to health (9th ed.). Belmont, CA: Wadsworth/Thomson.

Hamilton, M., \& Redmond, G. (2010). Conceptualisation of social and emotional wellbeing for children and young people, and policy implications: A research report for Australian Research Alliance for Children and Youth and the Australian Institute of Health and Welfare. Sydney, NSW: Australian Research Alliance for Children and Youth.

Haron, S. (1995). The Framework and concept of Islamic interest-free banking. Journal of Asian Business, 11(1), 26-39.

Haron, S., \& Hisham, B. (2003). Wealth mobilization by Islamic banks: the Malaysian case. Paper presented at the International Seminar on Islamic Wealth Creation, University of Durham, Durham, UK.

Hassan, N., \& Musa, M. (2003). An evaluation of the Islamic banking development in Malaysia. Paper pre- 
sented at the International Islamic Banking Conference, Kuala Lumpur, Malaysia.

Hearn, B., Piesse, J., \& Strange, R. (2012). Islamic Inance and market segmentation: Implications for the cost of capital. International Business Review, 21(1), 102-113.

Helliwell, J. F. (2006). Wellnbeing, social capital and public policy: what's new? The Economic Journal, 116(510), C34-C45.

Iqbal, M., \& Molyneux, P. (2005). Thirty years of Islamic banking. History, perfornance and prospects: Palgrave Macmillan.

Ismail, A. G., \& Arshad, N. C. (2010). Pricing on the Islamic banking products. Malaysian Management Review, 45(1), 37-60.

Ismail, A. H. (2002). The deferred contracts of exchange: Al-Quran in contrast with the Islamic economists' theory on banking and finance: Institute of Islamic Understanding Malaysia.

Jan, S. (2011). Evaluating the performance of Islamic banks in suggesting an Islamic model of development. Mimeograph. Durham Centre for Islamic Economics and Finance, Durham University, UK).

Jan, S., Khan, Z., \& Ullah, K. (2018). Institutionalising Justice in Islamic Finance. Journal of Islamic Economics, Banking and Finance, 14(1),205-216

Jan, S., Ullah, K., \& Asutay, M. (2015). Knowledge, work, and social welfare as Islamic socioeconomic development goals. Journal of Islamic Banking and Finance, 32(3), 9-19.

Jazil, T. (2013). The performace measures of selected Malaysian and Indonesian Islamic banks based on the Maqasid al-Shari'ah approach. IJTIHAD, 7(2), 279-301

Kamali, M. H. (2008). Shari'ah law: An introduction: Oneworld Publications, UK.

Khan, F. (2010). How 'Islamic'is Islamic Banking? Journal of Economic Behavior E Organization, 76(3), 805-820.

Lahsasna, A., \& Sulaiman, R. (2010). Realizing Maqasid al Shari'ah in Islamic Financial Planning. Paper presented at the A Paper presented at the 4th Islamic Banking, Accounting and Finance Seminar.

Lewis, M. K., \& Algoud, L. M. (2001). Islamic Banking. Cheltenham, UK and Northampton, USA: Edward Elgar.

Licht, AN., Goldschmidt, C \& Schwartz, SH. (2001). Culture, law, and finance: cultural dimensions of corporate governance laws. Retrieved from Social Science Research Network at http://papers.ssrn. com/sol3/papers.cfm?abstract_id=277613.

Lightman, E., Mitchell, A., \& Wilson, B. (2008). Poverty is making us sick: A comprehensive survey of income and health in Canada. Retrieved from http://www.wellesleyinstitute.com/publications/poverty_is_ making_us_sick__a_comprehensive_survey_of_income_and_health_in_canada/

May, S. K., Cheney, G., \& Roper, J. (2007). The debate over corporate social responsibility. Oxford University 
Press.

Mohammad, M. O., \& Shahwan, S. (2013). The objective of Islamic economic and Islamic banking in light of Maqasid Al-Shariah: A critical review. Middle-East Journal of Scientific Research, 13(13), 75-84.

Mohammed, M. O., \& Taib, F. M. (2015). Developing Islamic banking performance measures based on Maqasid al-Shari'ah framework: Cases of 24 selected banks. Journal of Islamic Monetary Economics and Finance, 1(1), 55-77.

Myers, J., Sweeney, T., \& Witmer, M. (2005). A holistic model of wellness. Retrieved from http://www. yukonwellness.ca/holistic.php

Naqvi, S. N. H. (2016). Perspectives on morality and human well-being: A contribution to Islamic economics: Kube Publishing Ltd.

Nouman, M., \& Ullah, K. (2014). Constraints in the application of partnerships in Islamic banks: The present contributions and future directions. Business $\mathcal{E}$ Economic Review, 6(2), 47-62.

Nouman, M., Ullah, K., \& Gul, S. (2018). Why Islamic banks tend to avoid participatory financing? A demand, regulation, and uncertainty framework. Business $\mathcal{E}$ Economic Review, 10(1), 1-32.

Nyazee, I. A. K. (2002). Islamic law of business organization partnerships. Herndon, USA: International Institute of Islamic Thought.

Osberg, L. (2014). Index of Economic Well-Being. Encyclopedia of Quality of Life and Well-Being Research, 123(1), 3161-3163.

Rawlins, B. L. (2006). Prioritizing stakeholders for public relations. Retrieved from https://instituteforpr. org/wp-content/uploads/2006_Stakeholders_1.pdf

Ryan, R. M., \& Deci, E. L. (2001). On happiness and human potentials: A review of research on hedonic and eudaimonic well-being. Annual Review of Psychology, 52(1), 141-166.

Ryff, C. D., \& Singer, B. H. (2006). Best news yet on the six-factor model of well-being. Social Science Research, 35(4), 1103-1119.

Satkunasegaran, E. (2003). Corporate governance and the protection of customers of Islamic banks. Paper presented at the paper presented at International Islamic Banking Conference rato, Italy.

Shinkafi, A. A., \& Ali, N. A. (2017). Contemporary Islamic economic studies on Maqasid Shari'ah: a systematic literature review. Humanomics, 33(3), 315-334.

Siddiqui, M. N. (1985). Partnership and profit-sharing in Islamic law. Leicester, UK: The Islamic Foundation.

Siddiqui, S. H. (2001). Islamic banking: True modes of financing. New Horizon, 109(2), 15-20.

Travis, J. W., \& Ryan, R. S. (2004). Wellness workbook: How to achieve enduring health and vitality: Random House Digital, Inc. 
Ullah, K., \& Al-Karaghouli, W. (2017). Understanding Islamic financial services: Theory and practice: Kogan Page Publishers.

Ullah, K., \& Patel, N. V. (2011). Addressing emergent context of shariah compliant financial services: A service designing construct. International Review of Business Research Papers, 7(3), 81-93.

Yusob, M. M., Salleh, M., Haron, A., Makhtar, M., Asari, K., \& Jamil, L. (2015). Maqasid al-Shariah as a parameter for Islamic countries in screening international treaties before ratification: An analysis. PERTANIKA Journal of Social Science and Humanities, 23(S), 219-226. 